\title{
PERANAN PEMBELAJARAN MATEMATIKA UNTUK MENUMBUHKAN JIWA BERWIRAUSAHA SISWA SMK KOTA BEKASI
}

\author{
Dellia Mila Vernia \\ Universitas Indraprasta PGRI \\ E-mail: delliamilavernia@gmail.com
}

\begin{abstract}
Abstrak
Penelitian ini memiliki tujuan untuk mengetahui dan meningkatkan jiwa berwirausaha melalui mata pelajaran matematika di SMK Insan Mulia Bekasi. Jumlah pengusaha atau wirausaha di Indonesia jika dibandingkan dengan negara lain di wilayah Asia negara masih kalah jauh, karena pengusaha di Indonesia masih sedikit. Salah satu wadah dalam pembentukan karakter dan nilai pada anak yaitu di sekolah, dan sekolah juga sebagai salah satu sarana tempat belajar mengajar. Siswa diajari banyak hal, seperti halnya diajari tentang how to know dan juga how to do. Rendahnya jiwa berwirausaha siswa dan masih adanya siswa yang tidak memiliki pemahaman yang cukup tentang pentingnya jiwa berwirausaha menjadi salah satu faktor penting untuk mewujudkan tujuan dari penelitian ini. Adapun dalam penelitian ini metode yang digunakan adalah metode sampel purposive (purposive sample). Berdasarkan hasil penelitian, siswa SMK Insan Mulia memiliki karakter berwirausaha, hal ini terlihat dari jawaban kuesioner yang sudah diberikan. Matematika memiliki peranan penting untuk menumbuhkan jiwa berwirausaha di SMK Insan Mulia, terutama dalam pembelajaran geometri yang berdampak pada produk kreatif yang sangat berguna untuk dunia usaha. Hambatan yang dihadapi siswa dalam mempelajari matematika dalam menumbuhkan jiwa berwirausaha diantaranya yaitu soal matematika yang sudah diberikan belum dapat menumbuhkan jiwa berwirausaha seperti ketekunan dan keuletan. Hal ini dikarenakan masih banyak kesukaran dalam menjawab soal tersebut.Solusi dalam mengatasi hambatan untuk meningkatkan jiwa berwirausaha siswa SMK Insan Mulia diantaranya, harus memperbanyak soal-soal matematika sehingga menumbuhkan keuletan dan ketekunan yang berdampak dalam menumbuhkan jiwa berwirausaha pada siswa.
\end{abstract}

Kata Kunci: Pembelajaran matematika, jiwa berwirausaha, kewirausahaan

\section{THE ROLE OF MATHEMATICS LEARNING TO GROW SOUL OF ENTREPRNEURSHIP OF SMK STUDENTS IN BEKASICITY}

\begin{abstract}
This study aims to find out and improve the spirit of entrepreneurship through mathematics subjects at SMK Mulia Insan Bekasi. Entrepreneurs or entrepreneurs in Indonesia are still small compared to other countries in Southeast Asia. School as one of the facilities for teaching and learning is a place for character building and values in children. At school, students are not only taught how to know about a material but how to do it. The low mentality of student
\end{abstract}


entrepreneurship and the presence of students who do not have sufficient understanding of the importance of the spirit of entrepreneurship is one of the important factors to realize the objectives of this study. The method used in this research is purposive sample method (purposive sample). Based on the results of the study, the students of Vocational High School of Mulia People have entrepreneurial character; this is can be seen from the answers in the questionnaires that have been given. Mathematics has an important role to foster entrepreneurship at SMK Insan Mulia, especially in learning geometry which has an impact on creative products that are very useful for the business world. The obstacles faced by students in learning mathematics in cultivating entrepreneurship include the mathematical problem that has been given yet to be able to foster entrepreneurial spirit such as perseverance and tenacity. This is because there are still many difficulties in answering these questions. The solution to overcoming barriers to increasing the entrepreneurial spirit of SMK Mulia Insan students, among them, must multiply mathematical questions so as to foster tenacity and perseverance that have an impact on growing entrepreneurship in students.

Keywords: Mathematics learning, entrepreneurial soul, entrepreneurship

\section{PENDAHULUAN}

Negara Indonesia adalah sebuah negara dengan pertumbuhan penduduk yang sangat cepat dan semakin meningkat. Namun kondisi tersebut tidak diikuti oleh laju pertumbuhan ekonomi dan lapangan pekerjaan yang memadai. Pendidikan merupakan salah satu cara dan solusi terbaik untuk mengatasi masalah tersebut. Karena dengan adanya pendidikan maka lulusan yang unggul dan berkualitas dapat dipersiapkan.

Untuk mempersiapkan manusia unggul, salah satunya melalui pendidikan yang harus melalui proses pembelajaran, pengetahuan, keterampilan, dan kebiasaan sehingga dapat memenuhi kebutuhan dan kepuasan hidup setiap manusia. Pendidikan secara aktif dan otomatis dapat mengembangkan potensi diri yang ada pada setiap manusia untuk mewujudkan tercapainya individu yang memiliki semangat juang tinggi dalam menghadapi tantangan global. Sehingga dapat dikatakan bahwa pendidikan mempunyai peranan yang penting dalam menghasilkan sumber daya yang berkualitas. Pendidikan yang berkualitas tinggi merupakan salah satu cita- cita bangsa Indonesia agar mampu bersaing dan berkompetisi di era globalisasi.

Jenjang pendidikan sekolah terdiri dari pendidikan dasar, pendidikan menengah dan pendidikan tinggi. Pendidikan menengah diselenggarakan untuk melanjutkan atau memperluas pendidikan dasar serta menyiapkan peserta didik menjadi anggota masyarakat yang memiliki kemampuan dalam bersosialisasi dengan lingkungan sekitar baik lingkungan ilmu budaya dan lingkungan ilmu alam sekitar serta dapat mengembangkan kemampuannya lebih lanjut dalam dunia kerja atau pendidikan tinggi.

Melalui pendidikan, khususnya, pendidikan kewirausahaan, diharapkan dapat meningkatkan kualitas sumber daya manusia, salah satu upaya yang dilakukan pemerintah Indonesia dalam menciptakan sumber daya yang berkualitas yaitu melalui jenis pendidikan kewirausahaan melalui pembelajaran matematika. Mata pelajaran matematika pada umumnya belajar tentang hitung-hitungan yang sederhana anak diajak untuk paham bagaimana matematika sangat berguna dan mengasyikkan. Selain mata pelajaran lainnya, matematika juga 
merupakan mata pelajaran yang sudah diajarkan sedari dini saat anak memasuki pendidikan formal yaitu di sekolah matematika diajarkan dengan cara yang sederhana, menarik dan mudah dipahami. Pendidikan menengah terdiri dari pendidikan umum, pendidikan kejuruan, pendidikan luar biasa, pendidikan kedinasan dan pendidikan agama. Salah satu bentuk pendidikan menengah adalah Sekolah Menengah Kejuruan (SMK). Menurut Undang-Undang Sistem Pendidikan Nasional 2003 Pasal 15 menyebutkan bahwa "pendidikan kejuruan merupakan pendidikan menengah yang mempersiapkan peserta didik terutama untuk bekerja, dalam bidang tertentu". Hal ini sejalan dengan tujuan Sekolah Menengah Kejuruan (SMK) yaitu menciptakan tenaga kerja tingkat menengah, siswa diharapkan mampu mengisi kebutuhan tenaga kerja pada instansi pemerintah maupun swasta. Siswa SMK setelah lulus akan mencari pekerjaan sesuai dengan keahlian yang dimiliki. Walaupun demikian tidak semua lulusan SMK mendapatkan pekerjaan sehingga dapat menimbulkan penggangguran. Kenyataannya, sekolah dan universitas memiliki peranan penting dalam memotivasi dan memfasilitasi serta mengarahkan dan menyediakan sarana dan prasarana dalam mempersiapkan peserta didik untuk memiliki motivasi kuat, keberanian serta kemampuan dan karakter pendukung dalam mendirikan bisnis baru.

Kurikulum pendidikan di Indonesia khususnya pendidikan dasar dan menengah wajib memuat beberapa pelajaran salah satunya adalah matematika. Dalam dunia pendidikan, matematika diakui tidak hanya sebagai bagian dari kurikulum, tetapi bagian yang sangat penting kegunaannya untuk diterapkan dalam kehidupan sehari-hari serta sangat menentukan dalam beberapa karir di masa depan. Pentingnya matematika sudah selayaknya matematika dapat dipelajari di sekolah untuk membekali siswa di masa depan.

Kewirausahaan adalah salah satu alternatif bagi masyarakat untuk mengatasi masalah ekonomi dan kemiskinan. Mata pelajaran kewirausahaan selain untuk sarana belajar perekonomian mandiri juga digunakan sebagai salah satu sarana para siswa siswi untuk mengaktualisasikan diri dalam perilaku dan pola pikir seorang wirausaha. Pembelajaran kewirausahaan difokuskan tertuju pada perilaku para wirausaha sebagai salah satu fenomena empiris yang terlihat dan terjadi di lingkungan siswa saat ini. Oleh karena itu, siswa diharapkan agar lebih aktif untuk mempelajari peristiwa ekonomi terutama yang berkaitan dengan kewirausahaan yang ada di lingkungan mereka untuk memaksimalkan potensi dan kemampuan serta karakteristik wirausaha yang dimiliki dalam diri setiap siswa.

Pendidikan kewirausahaan sangat cocok apabila diterapkan di SMK karena di SMK telah menerapkan pendidikan teknik dan kejuruan. Usman dan Raharjo (2012) menyatakan bahwa SMK merupakan sekolah yang memberikan berbagai keterampilan yang unggul komparatif (memiliki kemampuan dan keahlian dalam menghasilkan suatu barang dan jasa dengan biaya yang efektif dan efisien) dan unggul kompetitif (kemampuan berdaya saing untuk lulusan SMK). Jadi, jelas bahwa SMK merupakan sekolah yang cocok untuk penerapan pendidikan kewirausahaan.

Penerapan

Pendidikan

kewirausahaan di SMK tidak dapat berdiri sendiri. Hal ini dikarenakan pendidikan kewirausahaan tidak dapat berdiri sendiri tanpa mata pelajaran lain. Power (2009) menyatakan bahwa dalam pelaksanaan pendidikan kewirausahaan di diharapkan siswa telah memiliki keterampilan dasar seperti matematika, bahasa asing, keterampilan komputer, keterampilan 
berpikir seperti kreativitas, pemecahan masalah dan pengambilan keputusan serta keterampilan pribadi seperti sosialisasi, harga diri, kemandirian, manajemen diri dan integritas. Jadi jelas, bahwa pendidikan kewirausahaan memerlukan dukungan dari mata pelajaran lain diantaranya adalah matematika dan kalkulasi grafika.

Berdasarkan data yang dihimpun dari Badan Pusat Statistik (BPS) tercatat bahwa Tingkat Pengangguran Terbuka (TPT) pada periode bulan Februari 2016 sebesar 5,50 persen. Arti dari angka tersebut yaitu, dari 100 angkatan kerja, terdapat sekitar 5 hingga 6 orang berstatus penganggur. Jika dilihat dari tingkat pendidikan, maka Tingkat Pengangguran Terbuka (TPT) untuk pendidikan kejuruan SMK menduduki posisi tertinggi sebesar 8,84 persen. Kemudian disusul oleh TPT tingkat Diploma I/II/III sebesar 7,22 persen. Dengan kata lain, pada setiap 100 angkatan kerja lulusan SMK masih terdapat 9 sampai 10 orang lulusan SMK saat dengan saat ini yang menganggur. Hal ini menunjukkan bahwa masih ada lulusan SMK yang belum sesuai dengan kebutuhan perusahaan sehingga menimbulkan banyaknya lulusan yang masih menganggur dan menempati posisi pekerjaan tidak sesuai dengan keterampilan yang mereka dapatkan di SMK.

Jika mendapati kenyataan yang dihadapi ini, maka dirasakan perlu adanya arah pembentukan bagi siswa sebagai seorang individu yang dirasa mampu untuk menciptakan pekerjaan bukan lagi hanya sebagai pencari pekerjaan, solusinya yaitu dengan berwirausaha, maka untuk menuju ke arah pembentukan wirausaha ini, peran mata pelajaran matematika memiliki peranan kuat untuk menumbuhkan jiwa wirausaha pada siswa-siswa disekolah, khususnya siswa SMK.

Kenyataan saat ini, para pengusaha atau wirausaha yang ada di Indonesia masih sedikit dibandingkan dengan negara lain di
Asia Tenggara. Singapura masih menjadi negara yang terdepan dalam mencetak pengusaha di ASEAN. Jumlah wirausaha yang ada di Indonesia baru sekitar 1,65\% dari total jumlah penduduk yang ada. Singapura 7\%, Malaysia 5\% dan Thailand 3\% (Sindo, 2018). Namun survey Global Entrepreneurship Monitor (GEM) pada tahun 2013 tentang keinginan berwirausaha di Indonesia menempati peringkat kedua negara ASEAN yang memiliki keinginan tertinggi untuk berwirausaha setelah Filipina. Dengan keadaan ini, harus ditunjang dengan pendidikan di sekolah yang harus menumbuhkan jiwa kewirausahaan kepada siswa. Hal ini juga sejalan dengan realita di SMK Insan Mulia Bekasi, yang berusaha memotivasi para siswa agar mau untuk mewujudkan cita-cita menjadi seorang entrepreneur/wirausaha dan siap terjun di masyarakat.

\subsection{Pengertian Jiwa}

Jiwa wirausaha sangat diperlukan untuk meningkatkan daya saing. Secara teoritis pernyataan ini mengacu pada pengertian jiwa wirausaha dan daya saing yang ada di dalam Kamus Besar Bahasa Indonesia (KBBI). Menurut KBBI (Depdiknas, 2009) jiwa mempunyai tiga pengertian, yaitu: 1. Terdapatnya roh manusia (yang terdapat didalam tubuh dan menyebabkan seseorang dapat hidup), 2. Seluruh kehidupan yang terdiri atas batin manusia (meliputi perasaan, angan-angan, dan semangat), dan 3. Sesuatu atau sumber utama seseorang yang menjadi sumber tenaga dan semangat.

\subsection{Pengertian Berwirausaha}

Menurut pengertian secara etimologi, Asal kata kewirausahaan berasal dari kata wira dan usaha. Wira memiliki arti pejuang, pahlawan, manusia unggul, teladan, berbudi luhur, gagah berani dan memiliki watak agung. Sedangkan usaha artinya bekerja, 
berbuat sesuatu. Jadi pengertian wirausaha artinya adalah pejuang atau pahlawan yang berbuat sesuatu. Adapun menurut Kamus Besar Bahasa Indonesia, seorang wirausaha merupakan orang yang pandai dan berbakat dalam mengenali suatu produk yang baru, dan bisa menentukan cara produksi yang baru, serta bisa menyusun operasional untuk pengadaan produk baru, serta mengatur permodalan operasi produk dan serta mampu memasarkannya. Dalam lampiran keputusan Menteri Koperasi dan Pembinaan Pengusaha Kecil 961/KEP/M/XI/1995, dicantumkan bahwa: wirausaha merupakan orang yang mempunyai semangat, sikap, perilaku serta kemampuan dalam hal kewirausahaan.

Kewirausahaan memiliki arti luas, artinya, memiliki semangat, sikap, perilaku dan kemampuan seseorang dalam hal menangani, mengembangkan dan menjalankan usaha dan kegiatan yang mengarah pada upaya mencari, menciptakan, serta mengimplementasikan cara kerja, serta teknologi yang tinggi dan produk baru yang didukung dengan peningkatan efisiensi dalam rangka pemberian pelayanan agar lebih baik dan bisa memperoleh keuntungan yang lebih besar. Keuntungan menjadi wirausahawan banyak sekali, diantaranya yaitu memiliki kebebasan mencapai tujuannya serta impian seseorang dengan menunjukkan potensi yang dimiliki secara penuh sehingga memberikan laba maksimal. Dan juga kebebasan untuk melakukan perubahan dan serta menciptakan peluang lapangan pekerjaan dan juga bisa mendapatkan pengakuan dari masyarakat, hal ini merupakan salah satu keuntungan berwirausaha. Wirausaha memiliki arti menjalankan usaha. Menurut pendapat Tedjasutisna (2009) yang menyatakan bahwa "wirausaha merupakan individu manusia yang mempunyai kemampuan melihat dan mengambil kesempatan- kesempatan dalam bidang bisnis, lalu dengan kesadaran mau mengumpulkan sumber-sumber data valid yang dibutuhkan agar bisa mengambil keuntungan dan tindakan yang tepat guna memastikan mencapai kesuksesan. Menurut Alma (2013) wirausaha adalah individu yang berperan sebagai seseorang yang inovator. Sebagai individu yang memiliki naluri dan nurani untuk melihat sebuah peluang, memiliki semangat, serta kemampuan dan pikiran untuk menaklukkan cara berpikir yang lamban dan malas.

Menurut Kasmir (2017) Sekitar abad 18 yang diawali dengan penemuanpenemuan baru seperti mesin uap, mesin pemintal dan lainnya, bersamaan dengan dikenalnya kewirausahaan pertama kali pada masa itu. Melalui inovasi dan kreativitas maka tujuan utama yang hendak dicapai adalah adanya pertumbuhan dan perluasan organisasi. Hendro (2011) menjelaskan pengertian kewirausahaan adalah merupakan usaha yang kreatif dalam membangun sesuatu nilai dari yang belum ada menjadi ada dan akhirnya bisa dinikmati oleh orang banyak. Sedangkan Dewanti (2008) mendefinisikan wirausahawan ialah orangorang yang mampu dan siap menjawab tantangan dan mau memanfaatkan peluang yang ada untuk menciptakan tujuan sehingga dapat meningkatkan kesejahteraan hidup pada diri sendiri maupun lingkungan yang lebih luas.. Adapun ciri-ciri yang harus dimiliki seseorang untuk menjadi seorang wirausahawan yang sukses yaitu harus mau melihat dan memiliki visi jauh kedepan, dan dapat berpikir dengan penuh perhitungan yang matang serta dapat mencari pilihan dari berbagai alternative dalam mencari solusi atas pemecahan masalah yang dihadapinya. Meredith dalam Suharyadi (2010) menjelaskan ciri-ciri wirausahawan adalah sebagai berikut:

a. Percaya diri. Ketika seseeorang yang memiliki kepercayaan diri yang tinggi 
harus dimiliki oleh seorang pengusaha. Karena segala sesuatu yang telah diyakini dan dianggap benar harus dilakuakn sepanjang tidak melanggar hokum dan norma yang berlaku. Percaya diri merupakan sikap dan keyakinan untuk memulai dan melakukan suatu usaha dan kegiatan serta menyelesaikan tugas dan pekerjaan yang dilaksanakan

b. Memiliki orientasi pada tugas dan hasil. Seorang wirausaha harus bisa fokus dan memiliki target pada tugas dan hasil yang ingin dicapai. Apa yang sudah dilakukan oleh wirausahawan merupakan suatu usaha kerja keras guna mencapai tujuan yang telah ditentukan. Keberhasilan pencapaian tugas tersebut ditentukan oleh faktor motivasi untuk berprestasi, berorientasi keuntungan, serta kemauan kerja keras dan memiliki inisiatif.

c. Berani dan mau untuk mengambil resiko. Setiap proses bisnis apapun pasti memiliki resiko baik dalam skala besar maupun kecil. Untuk memperkecil peluang kegagalan usaha maka wirausahawan harus mengetahui peluang kegagalan, maka dengan langkah tersebut bisa memperkecil resiko.

d. Kepemimpinan. Wirausahawan yang berhasil diharapkan mempunyai kemampuan dalam hal memimpin karyawan dan bisnisnya, bukan hanya dapat memberikan pengaruh kepada seluruh jajaran karyawannya namun juga memiliki sikap tangkas dan sigap dalam hal mengatasi setiap perubahan yang dihadapi.

e. Nilai keorisinilan. Nilai sebuah kewirausahaan salah satunya harus mampu menciptakan sesuatu yang baru dan berbeda dari yang lain. Keunikan yang terdapat pada suatu barang dan jasa harus bisa menjadi pembeda dan daya tarik tersendiri dalam proses berwirausaha dan berorientasi pada masa depan. Wirausahawan harus memiliki pandangan yang jauh kedepan sehingga menjadi tujuan dalam hal upaya dan penciptaan usahanya agar terus maju dan berinovasi sehingga memiliki produk dan jasa yang berbeda dari lainya. Para wirausahawan memiliki pola pikir dan pandangan untuk merasa tidak cepat puas sehingga harus terus mencari peluang. Kepekaan juga harus dimiliki wirausahawan terhadap lingkungan yang ada di sekitar untuk menciptakan produk yang memiliki orientasi pada masa depan.

Dari berbagai pengertian dan pendapat yang dikemukakan beberapa ahli di atas, maka dapat disimpulkan bahwa wirausaha adalah proses pada seseorang untuk mau melakukan upaya-upaya yang kreatif dan inovatif, salah satunya dengan cara mengembangkan ide dan gagasan, serta mampu meramu sumber daya untuk menemukan sebuah peluang dan perbaikan taraf hidup.

\subsection{Pengertian Jiwa Berwirausaha}

Dengan memiliki jiwa kewirausahaan pada setiap individu maka bisa memotivasi seseorang agar lebih sukses dalam meraih dan mencapai tujuan yang diinginkan pada era globalisasi saat ini. Karena dengan memiliki jiwa berwirausaha maka setiap individu akan memiliki semangat juang yang lebih tinggi untuk mencapai tujuan usahanya. Dengan adanya krisis ekonomi khususnya di Indonesia beberapa waktu lalu, memberikan dampak besar, terutama untuk peluang pekerjaan. Oleh karena itu, para pencari kerja saat ini, dituntut agar bisa menciptakan lapangan pekerjaan bukan hanya untuk dirinya sendiri, tapi juga untuk orang lain. Sehingga usaha yang dirintisnya bisa membuka lapangan pekerjaan baru bagi orang lain.Seorang wirausaha harus memiliki kemampuan untuk melihat jauh kedepan 
dengan penuh perhitungan, untuk mencari solusi atas permasalahan yang ada pada usahanya.

Menurut Garjito (2014) bahwa jiwa kewirausahaan adalah dalam diri pribadi perorangan memiliki sebuah tujuan yang jelas atau visi hidup dan mampu mengubahnya menjadi sebuah kenyataan bisnis dan dalam mencapai hal tersebut seserorang itu mampu membuat sebuah keputusan dalam membantu terbentuknya sistem ekonomi perusahaan. Sedangkan menurut Dan Stein Hoff dan Jhon dalam (Garjito: 2014) jiwa kewirausahaan merupakan individu yang mampu dan memiliki kemampuan untuk mengorganisasikan, mengelola serta berani mengambil resiko untuk mencapai dan mewujudkan usaha dan peluang baru, dan juga memiliki sikap mental, pandangan serta wawsan dalam tindakan yang berorientasi pada pelanggan. Adapun menurut Hartanti (dalam Widiyatnoto, 2013) jiwa kewirausahaan merupakan suatu perilaku berwirausaha yang ditunjukkan melalui sifat dan sikap seseorang dalam memajukan suatu usahanya melalui gagasan inovatif yang diwujudkan dalam langkah nyata usahanya. Lain pula pendapat Suryanto (2009) jiwa kewirausahaan merupakan jiwa yang dimiliki seseorang itu haruslah kreatif dan inovatif sehingga mampu mendirikan, membangun, mengembangkan serta memajukan suatu usaha dan mewujudkannya dalam usaha yang unggul. Jiwa kewirausahaan merupakan suatu sikap yang dimiliki seseorang terdiri dari percaya diri, disiplin tinggi, mandiri, optimism, berpikir positif, ulet dan berani mengambil resiko dalam menjalankan dan mengembangkan usahanya (Justin: 2009).

Menurut Leonardus (2009) agar memiliki jiwa kewirausahaan dalam diri seseorang harus memiliki kemampuan dalam dirinya, antara lain: a. Mengarahkan diri

Untuk menjadi seorang pengusaha yang sukses, pengusaha harus memiliki sikap disiplin diri yang tinggi. Karena sebagai pemilik suatu usaha, maka seorang entrepreneur merupakan penanggung jawab atas keberhasilan yang hendak dicapai oleh usahanya.

b. Percaya diri

Seorang entrepreneur harus memiliki kepercayaan diri akan inovasi dan ide usaha yang dimilikinya walaupun tidak ada satupun orang yang mendukung dan mempercayai ide tersebut.

c. Berorientasi pada tindakan

Suatu ide dan gagasan harus diwujudkan dalam sebuah tindakan nyata, oleh karena itu seorang entrepreneur harus mau mewujudka ide tersebut pada sebuah tindakan nyata.

d. Energik

Dalam menjalankan sebuah bisnis, harus memiliki suatu sikap dan semangat yang mendukung usaha tersebut agar berjalan dengan lancer dan sesuai dengan target yang ingin dicapai.

e. Toleran terhadap ketidakpastian

Seorang entrepreneur harus berani menghadapi tantangan dan hambatan serta resiko yang tidak terduga.

Sedangkan menurut Suryana (2009) seorang yang memiliki jiwa kewirausahaan haruslah memiliki ciri-ciri sebagai berikut:

a. Penuh percaya diri

Seseorang yang memiliki kepercayaan diri yang tinggi diliputi oleh keyakinan, optimism, komitmen, disiplin diri serta rasa tanggung jawab tinggi. 
b. Memiliki inisiatif

Entrepreneur harus berinisiatif dalam mengembangkan usahanya, sikap yang harus dimiliki antara lain, harus memiliki energy untuk bertindak, cekatan dalam bekerja serta proaktif dalam menyikapi setiap perubahan yang serba cepat.

c. Memiliki motif berprestasi

Seorang entrepreneur harus memiliki motivasi tinggi untuk mencapai hasil sesuai dengan target yang ingin dicapai.

\section{d. Memiliki jiwa kepemimpinan}

Seorang entrepreneur harus memiliki jiwa kepemimpinan hal ini dikarenakan harus mampu untuk memimpin usaha yang dikelola karena terdiri dari karyawan yang menjalankan usahanya dan tentu saja selain itu seorang pemimpin harus berani mengambil keputusan, sehingga harus berani tampil terdepan dan dapat dipercaya serta tangguh dalam bertindak dan bersikap.

e. Berani mengambil resiko

Dalam melakukan usaha bisnis, seorang entrepreneur harus memiliki kemampuan dalam perhitungan bisnis sehingga mampu melihat resiko yang akan dihadapi dalam usaha bisnisnya.

Indikator jiwa kewirausahaan dapat dijabarkan sebagai berikut:

a. Adanya kemauan yang kuat. Hal ini mengandung pengertian bahwa dalam menerapkan pengetahuan para siswa harus memiliki kemauan kuat untuk berkarya dan belajar agar bisa menerapkan pengetahuannya dalam dunia usaha itu sendiri. Untuk membangun usaha, kemauan yang kuat menjadi dasar dan sebagai bentuk komitmen dalam membangun usaha serta dalam belajar akan terlihat lebih sungguh-sungguh memperhatikan dan mencermati apa yang seharusnya diperoleh dan juga harus memiliki kemauan tinggi serta semangat dalam membuat keberhasilan yang dapat segera diwujudkan.

b. Memiliki kemampuan untuk mengambil keputusan tepat dalam bisnis, karena keputusan dilakukan dalam rangka memastikan benar arah dan tujuan yang hendak dibuat dan dicapai, keputusan dijadikan dasar tempat berpijak. Namun tentu saja selalu didasari oleh informasi yang tepat, dan informasi yang tepat menjadi dasar dalam mengambil keputusan tepat. Sedangkan informasi yang tepat bisa didapat dari pengolahan data yang akurat dan cermat.

c. Kreatif, menjadi kreatif artinya harus inovasi, karena inovasi inilah yang membuat berbeda karena memiliki keunikan dan keunggulan.

d. Tekun, makna kata tekun memiliki makna kata yang identik dengan makna rajin. Seseorang yang tekun, teliti dan produktif serta cekatan adalah bentuk sikap yang harus diterapkan oleh setiap siswa agar tidak cepat bosan dalam menghadapi kondisi yang berulangulang, karena kondisi inilah yang menjadikan keberhasilan tersebut menjadi sebuah kenyataan.

e. Etika bisnis, di dalam perjalanan berbisnis semua pihak menginginkan sebuah keuntungan. Namun keuntungan tersebut harus diperoleh dengan cara yang baik dan disenangi oleh banyak orang, sehingga akan memberikan usaha yang berkelanjutan.

f. Melakukan perubahan, artinya adalah keadaan yang harus segera diubah dan dilakukan karena dengan adanya perubahan akan ada sebuah harapan untuk mencapai hasil terbaik. 
g. Menangkap peluang, melalui sebuah bisnis atau usaha maka bisa dikatakan mampu untuk menghitung dengan cepat. Konsep peluang ini menjadi sebuah bagian penting dalam berusaha dan berbisnis, sehingga peluang itu bisa dicapai dalam waktu cepat.

Ada 5 karakteristik ciri-ciri wirausaha menurut Scarborough dan Zimmerer (dalam Suryana, 2011) yaitu:

a. Desire for responsibility bisa diartikan yaitu memiliki sebuah rasa tanggung jawab atas usaha yang dilakukannya.

b. Preference for moderate risk yaitu mau dan berani menghadapi resiko.

c. Desired for immediate feedback pengertiannya yaitu wirausaha dapat membalas umpan balik dengan cepat tanggap.

d. Future orientation yaitu memiliki orientasi ke masa depan.

e. Value of achievement over money: memiliki kemampuan dan keterampilan mengorganisasikan sumber daya agar menciptakan nilai tambah dalam sebuah bisnis.

\subsection{Pengertian Pembelajaran}

Menurut UU SISDIKNAS Pasal 1 Ayat (20) menyebutkan bahwa "Pembelajaran adalah proses interaksi peserta didik dengan pendidik dan sumber belajar pada suatu lingkungan belajar". Sedangkan Suherman (2010) menyatakan bahwa pembelajaran ialah membelajarkan siswa dengan menggunakan asas pendidikan maupun teori belajar merupakan sebuah penentu utama dalam keberhasilan pendidikan. Bisa dikatakan bahwa pembelajaran itu merupakan proses komunikasi dua arah, yaitu mengajar dilakukan oleh pihak guru sebagai pendidik, sedangkan belajar dilakukan oleh para peserta didik. Pembelajaran mengandung arti bahwa setiap kegiatan yang dirancang untuk membantu seseorang mempelajari akan suatu kemampuan dan atau nilai yang baru.

Pendapat (Sujiono: 2009) Faktor yang berpengaruh dalam pembelajaran dapat dilihat dari berbagai macam aspek diantara adalah:

a. Perkembangan sosial

Pembelajaran matematika merupakan pembelajaran yang tepat untuk saling bertukar ide dan berbagi ide dan hasil pengamatan dengan siswa yang lain. Berdasarkan aktivitas yang ada dalam penemuan matematika, maka diperlukan kemampuan dan kerjasama dengan orang lain. Setiap anak memiliki kemampuan untuk bekerja secara kelompok dan bekerja sama secara alamiah ketika mereka terlibat dalam aktivitas kelompok.

b. Perkembangan emosional

Setiap kegiatan dan aktiitas dalam penemuan dan penjelajahan ilmu pengetahuan sangat berpotensi mengembangkan rasa bangga dan saling menghargai, misalnya pada saat siswa mampu menemukan jawaban atau berhasil dalam kegiatan penjelajahan ilmu penegtahuan yang sedang dijalankannya. Belajar tentang fenomena alam atau makhluk hidup terkadang dapat terlihat "menakutkan" tetapi sebaliknya dapat juga membantu peserta didik untuk mengalahkan ketakutannya. Rasa heran dan dan kegembiraan dalam matematika akan muncul dan menambah kegembiraan 
peserrta didik dalam penjelajahan ilmu matematika sebagai ungkapan rasa keingintahuan mereka.

c. Perkembangan fisik

Peserta didik yang telah berkembang secara lebih dewasa dan matang secara emosional akan mudah menerima berbagai tantangan dan hambatan yang ada dalam berwirausaha, namun bagi yang belum matang secara emosional akan memiliki sikap mudah menyerah

d. Perkembangan sikap

Sikap (attitude) didefinisikan (Kaur: 2013) sebagai sebuah kondisi mental teroganisir melalu pengalaman, mengerahkan pengaruh dinamis direktif pada respon individu untuk semua obyek dan situasi yang terkait. Sikap ini didasarkan pada keyakinan dan sering memiliki andil untuk membimbing perilaku. Pengertian sikap menurut (Patta : 2009) menjelaskan bahwa suatu keadaan internal yang terbentuk dan bisa memberikan pengaruh tindakan terhadap benda atau suatu peristiwa. Salah satu jenis sikap yang disebutkan oleh Patta yaitu sikap ilmiah. Sedangkan menurut Janciraniet (2012) menjelaskan bahwa sikap ilmiah adalah kombinasi dari banyak kualitas dan kebaikan yang tercermin melalui perilaku dan tindakan orang tersebut. Orang-orang ini memiliki pikiran yang lebih terbuka (open minded), berorientasi percobaan, sistematis, dan memiliki kesukaan pada ilmu pengetahuan, meyakini kebenaran secara intelektual, jujur, bertindak ilmiah dan harapan bahwa solusi dari masalah yang akan datang melalui penggunaan pengetahuan diverifikasi. Sikap ilmiah diketahui memiliki 6 unsur, yang terkandung didalamnya yaitu keingintahuan (curiosity), spekulatif (speculativaness), kesediaan untuk bersifat obyektif (willingness to be objective), berpandangan terbuka (open minds), kesediaan untuk mengukuhkan keputusan (willingness to suspend judgement) dan kesediaan untuk bersikap bahwa semua penggunaan pengetahuan bersifat sementara (tentativity). Scientific attitude merupakan hal yang harus dimiliki pada semua tingkatan pendidikan Matematika menurut National curriculum Council (Patta; 2009) yaitu hasrat ingin tahu, rasa menghargai, kenyataan (fakta dan data), menerima ketidak pastian, refleksi kritis dan sikap hati-hati, tekun, ulet, tabah dan kreatif untuk menemukan hal baru, berpikir terbuka, sensitive terhadap lingkungan sekitar dan mau bekerja sama dengan orang lain. Gejala-gejala alam yang mempelajari tentang makhluk hidup dan makhluk tak hidup merupakan pengertian dari ilmu pengetahuan alam dan ilmu matematika. Belajar matematika berkaitan juga dengan mempelajari tentang matematika kehidupan dan matematika tentang dunia fisik. Berdasarkan pertanyaan "apa?" "mengapa?" dan "bagaimana?" maka diperoleh pengetahuan matematika kemudian dikembangkan dengan berlandaskan pada serangkaian penelitian tersebut serta penerapannya dalam teknologi dan kehidupan sehari-hari. Untuk lebih 
menekankan pada pemberian pengalaman secara langsung untuk mengembangkan kompetensi pada pendidikan matematika maka siswa diharapkan mampu menjelajahi dan lebih memahami alam sekitar secara ilmiah. Pengarahan pembelajaran matematika dengan cara mencari tahu secara langsung dan melakukan sesuatu secara mandiri sehingga dapat lebih membantu siswa untuk dapat memperoleh pemahaman yang lebih mendalam tentang alam sekitar.

Sehingga, cara pendekatan yang dilakukan dalam penyajian pembelajaran matematika adalah menyatukan pengalaman proses matematika dan pemahaman matematika dalam bentuk pengalaman langsung (Depdiknas, 2009). Kerja ilmiah merupakan hal-hal yang berkaitan dengan langkah-langkah dan metode ilmiah yang dikerjakan oleh ilmuwan dalam mendapatkan atas solusi permasalahan yang dihadapi. Diawali dengan adanya suatu masalah, maka ilmuwan akan mencoba mencari solusi yang didasarkan pada teori dan hipotesis sistematika. Langkah awal yang dilakukan dalam mencari pemecahakan masalah, terlebih dahulu dilakukan observasi, kemudian disusun dalam suatu hipotesis dari hasil observasi tersebut. Kemudian dilakukan pengujian hipotesis tersebut dengan melakukan eksperimen untuk memperoleh data. Selanjutnya data akan diolah hingga pada akhirnya akan memperolah suatu kesimpulan yang selanjutnya kesimpulan tersebut harus diuji kembali dengan eksperimen yang berulangulang hingga menunjukkan hasil yang sama dan membuktikan bahwa kesimpulan yang dibuat adalah benar, hingga dapat diterima kebenarannya dan dapat dianggap sebagai suatu teori atau hukum pembelajaran matematika disekolah dan menerapkan metode ilmiah dengan membiasakan peserta didik untuk melakukan kerja ilmiah. Peserta didik harus terbiasa dihadapkan pada suatu permasalahan yang kemudian dicari solusinya, hal ini berguna untuk memotivasi peserta didik untuk melakukan kerja ilmiah dengan menerapkan metode ilmiah. Adapun rumusan metode ilmiah antara lain observasi atau pengamatan terhadap lingkungan sekitar, merumuskan masalah dari hasil observasi, merumuskan suatu hipotesis yang merupakan jawaban sementara dari masalah yang sedang dihadapi, kemudian merancang suatu eksperimen untuk menguji hipotesis dan melaksanakan rancangan eksperimen untuk mendapatkan data, selanjutnya data dari hasil eksperimen dianalisis dan ditarik suatu kesimpulan yang merupakan pembuktian dari hipotesis tersebut. Suatu kesimpulan yang telah diuji lagi dengan eksperimen dan menunjukkan hasil yang sama dapat disebut sebagai teori atau konsep. Langkah terakhir dalam metode ilmiah adalah melaporkan hasil kerja ilmiahnya secara keseluruhan mulai dari rumusan masalah hingga hasil dari eksperiman yang merupakan suatu kesimpulan.

Berdasarkan pengertian diatas maka dapat disimpulkan bahwa pembelajaran adalah setiap aktivitas yang dirancang untuk membantu setiap orang untuk mempelajari sesuatu hal dalam suatu lingkungan belajar. 


\subsection{Pengertian Matematika}

Hudoyo (Anwar, 2009) menyatakan bahwa matematika merupakan terdiri dari ide-ide struktur-struktur dan hubunganhubungannya yang diatur menurut urutan yang logis. Sehingga dapat dikatakan bahwa, matematika berkaitan dengan konsep-konsep abstrak yang dikembangkan berdasarkan alasan-alasan yang logis dan jelas, sehingga dapat digunakan untuk membuktikan suatu pernyataan, benar atau salah. Belajar matematika tidak hanya berhubungan dengan bilangan-bilangan, struktur-struktur dan hubungannya yang diatur secara logis sehingga dapat dikatakan matematika berkaitan dengan konsepkonsep yang abstrak, selain hal tersebut, belajar matematika adalah suatu aktivitas yang berkaitan dengan mental untuk memahami arti dari struktur-struktur, hubungan-hubungan, dan simbol-simbol, kemudian menetapkan konsep-konsep yang dihasilkan ke situasi yang nyata sehingga menyebabkan suatu perubahan tingkah laku.

Sumarno (Kasim, 2009) mengemukakan beberapa hal yang berkaitan dengan karakteristik matematika, yaitu: materi pelajaran matematika menekankan penalaran yang bersifat deduktif, dan juga materi matematika bersifat hierarkis dan terstruktur sehingga dalam mempelajari matematika dibutuhkan ketekunan, keuletan serta rasa cinta dan suka terhadap matematika. Berdasarkan pendapat yang dikemukakan diatas, karena materi matematika bersifat hierarkis dan terstruktur maka dalam belajar matematika tidak boleh terputus-putus dan urutan materi harus lebih diperhatikan.

Menurut Fauzi dalam Supardi (2012) matematika adalah salah satu submateri tes kemampuan umum yang diberikan dan tidak bisa dihindarkan begitu saja. Dapat dikatakan matematika adalah ilmu pengetahuan yang dapat diaplikasikan pada ilmu pengetahuan lainnya. Sriyanto dalam Supardi (2012) mengatakan bahwasanya matematika mempunyai beberapa ciri penting, yaitu seperti: 1) Memiliki objek yang dapat dikatakan abstrak: karena objek matematika adalah fakta, konsep, operasi dan prinsip kesemuanya itu berperan dalam membentuk proses pikir matematis. 2) Memiliki pola deduktif dan konsisten: artinya matematika dikembangkan dengan cara dedukasi dan seperangkat anggapananggapan yang tidak dipersoalkan atau diperdebatkan lagi akan nilai kebenarannya karena dianggap sudah benar, matematika berpangkal dari hal-hal yang bersifat umum diterapkan atau diarahkan kepada hal-hal yang bersifat khusus. 3) Konsisten dalam sistemnya: matematika didalamnya terdapat banyak sistem. Sistem tersebut berkaitan satu sama lain, tetapi ada juga sistem yang dapat terlepas satu sama lain. Misalnya sistem-sistem aljabar dan sistem geometri.

\subsection{Pengertian Matematika}

Pembelajaran

Berdasarkan beberapa pengertian yang berkaitan dengan pembelajaran dan kewirausahaan maka dapat ditarik sebuah kesimpulan bahwa yang dimaksud pembelajaran matematika merupakan setiap kegiatan yang dirancang agar bisa membantu siswa untuk mempelajari matematika yang dapat diperoleh melalui teori di dalam kelas seperti kebiasaankebiasaan, pengetahuan dan sikap baru tentang kreativitas dan inovasi dalam memahami sebuah peluang, mengorganisasikan kumpulan sumbersumber yang ada, kemudian mengelolanya sehingga peluang itu dapat terwujud menjadi suatu usaha ataupun bisnis yang mampu menghasilkan keuntungan atau laba. 


\section{METODE}

Pada penelitian ini yang menjadi subyek penelitian adalah siswa SMK Insan Mulia Kota Bekasi. Peneliti menggunakan metode sampel purposif (purposif sample). Sampel dipilih karena memang menjadi sumber dan kaya dengan informasi mengenai fenomena yang akan diteliti.

\section{HASIL DAN PEMBAHASAN}

Pada angket pembelajaran matematika yang sudah di isi olehsiswa,sebanyak 25 siswa . Hasil dari angket tersebut dapat dilihat pada rincian pertanyaan dibawah ini.

\section{Pertanyaan 1}

Ketika waktu pertama kali saya mendapatkan pembelajaran matematika, saya percaya bahwa pembelajaran yang saya dapatkan ini akan terasa lebih mudah bagi saya.

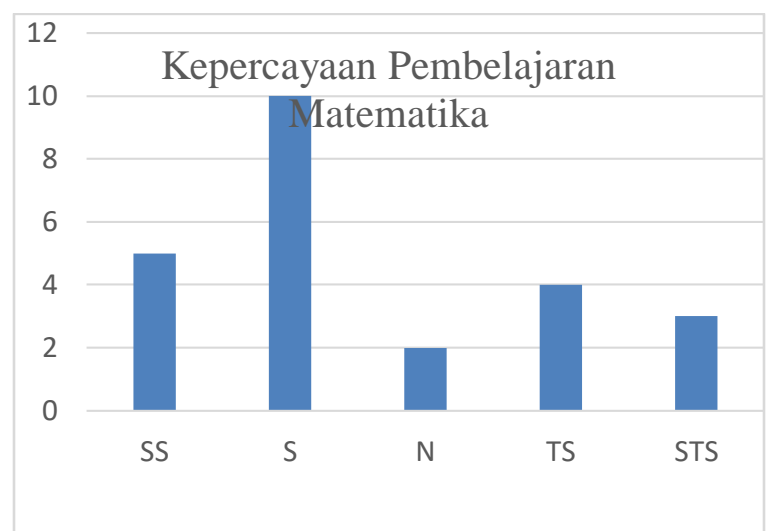

Diagram 1. Kepercayaan pembelajaran pada matematika

Siswa menjawab sangat setuju dan setuju ada sebanyak 15 siswa ,sedangkan yang menjawab tidak setuju dan sangat tidak setuju sebanyak 7 siswaserta yang netral sebanyak 2 siswa.
Pada data diatas ,sebagian besar siswa setuju (60\%) tentang, kepercayaan pembelajaran matematika.

\section{Pertanyaan 2}

Pada awal pembelajaran ada sesuatu yang menarik bagi saya.

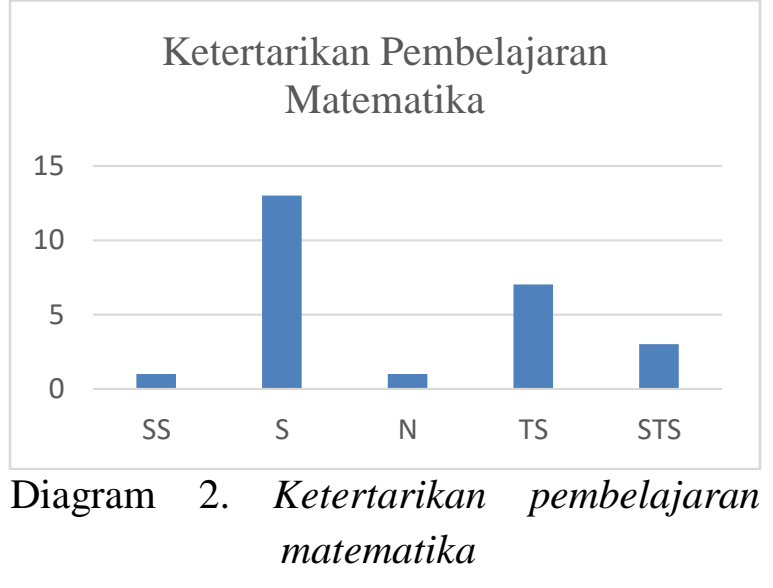

Siswa yang menjawab sangat setuju dan setuju sebanyak 14 siswa ,sedangkan yang menjawab tidak setuju dan sangat tidak setuju sebanyak 10 siswaserta yang netral sebanyak 1 siswa.

Pada data diatas ,sebagian besar siswa setuju (44\%) tentang, ketertarikan di awal pembelajaran matematika.

\section{Pertanyaan 3}

Materi pembelajaran matematika membantu saya dalam memahami perhitungan rugi laba dalam berwirausaha

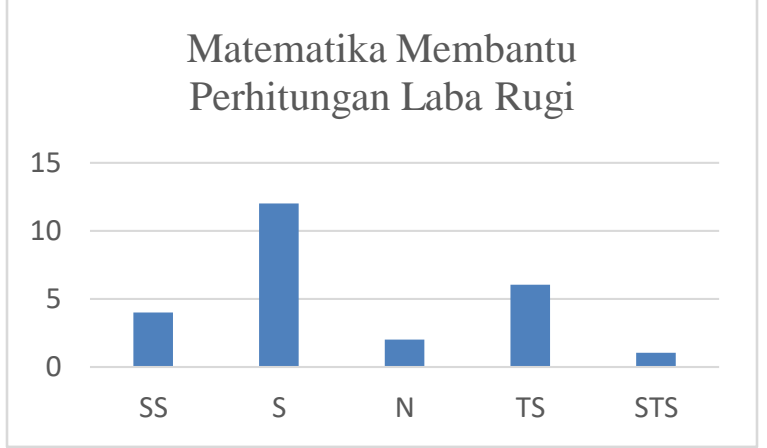

Diagram 3. Matematika membantu perhitungan laba rugi 
Sebanyak 16 siswa yang menjawab sangat setuju dan setuju, adapun siswa yang menjawab tidak setuju dan sangat tidak setuju sebanyak 7 siswa serta yang netral sebanyak 2 siswa.

Pada data diatas ,sebagian besar siswa setuju (64\%) tentang materi matematika membantu memahami perhitungan laba rugi.

\section{Pertanyaan 4}

Setelah belajar tentang berbagi bentuk bangun geometri seperti balok dan kubus, saya terinspirasi untuk kreatif dalam membuat produk

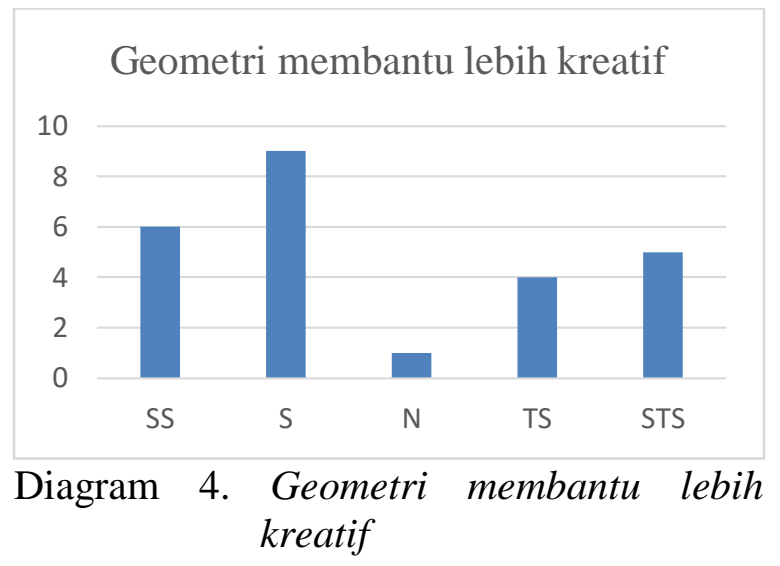

Siswa yang menjawab sangat setuju dan setuju sebanyak 15 siswa ,sedangkan yang menjawab tidak setuju dan sangat tidak setuju sebanyak 9 siswa serta yang netral sebanyak 1 siswa.

Pada data diatas ,sebagian besar siswa setuju (60\%) bahwa mempelajari bangun geometri membantu untuk lebih kreatif.

\section{Pertanyaan 5}

Setelah menyelesaikan tugas-tugas matematika yang diberikan guru, saya merasa puas dengan nilai yang saya capai.

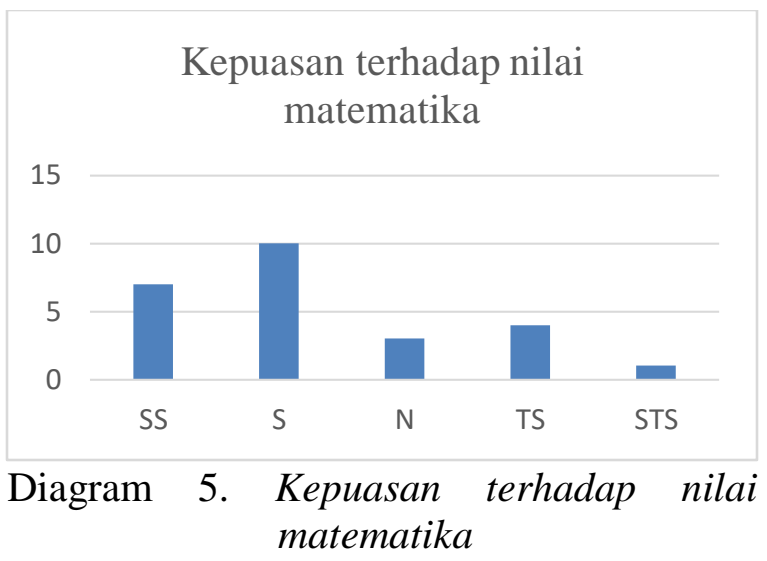

Terdapat 17 siswa yang menjawab sangat setuju dan setuju, sedangkan siswa yang menjawab tidak setuju dan sangat tidak setuju sebanyak 5 siswa serta yang netral sebanyak 3 siswa.

Pada data diatas ,sebagian besar siswa setuju $(68 \%)$ tentang kepuasan terhadap nilai tugas matematika yang sudah diberikan.

\section{Pertanyaan 6}

Hubungan antara materi pembelajaran matematika dengan kehidupan nyata, khususnya wirausaha, terlihat jelas bagi saya.

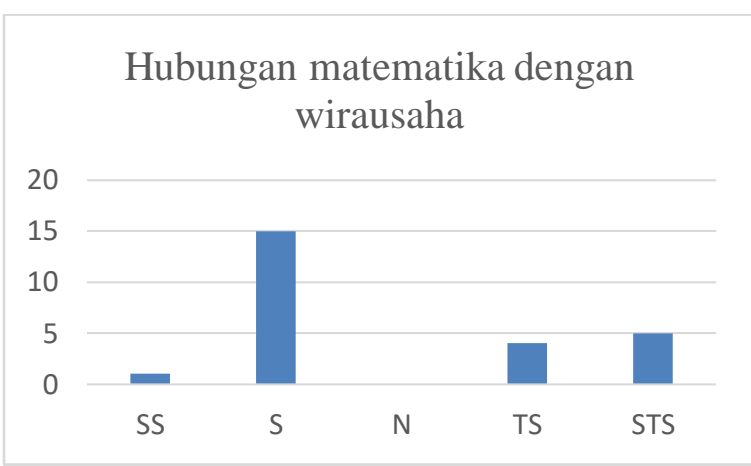

Diagram 6. Hubungan matematika dengan wirausaha

Total sebanyak 16 siswa yang menjawab sangat setuju dan setuju, adapun yang menjawab tidak setuju dan sangat tidak setuju sejumlah 9 siswa serta yang netral sebanyak 0 siswa.

Pada data diatas ,sebagian besar siswa setuju (64\%) tentang realita kehidupan 
yang berkaitan wirausaha dan pembelajaran matematika tampak jelas nyata.

\section{Pertanyaan 7}

Halaman-halaman buku yang begitu banyak memuat informasi membuat saya sukar untuk mengambil ide-ide penting dan mengingatnya.

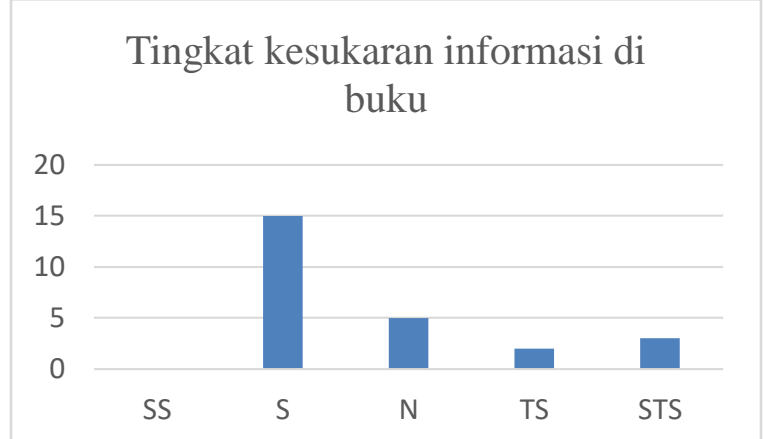

Diagram 7. Tingkat kesukaran informasi di buku

Siswa yang menjawab sangat setuju dan setuju sebanyak 15 siswa ,sedangkan yang menjawab tidak setuju dan sangat tidak setuju sebanyak 5 siswa serta yang netral sebanyak 5 siswa.

Pada data diatas ,sebagian besar siswa setuju (60\%) tentang kesukaran mengingat informasi penting yang terdapat pada setiap lembar halaman buku.

\section{Pertanyaan 8}

Materi pembelajaran matematika sangat menarik perhatian saya karena menunjang dunia wirausaha.

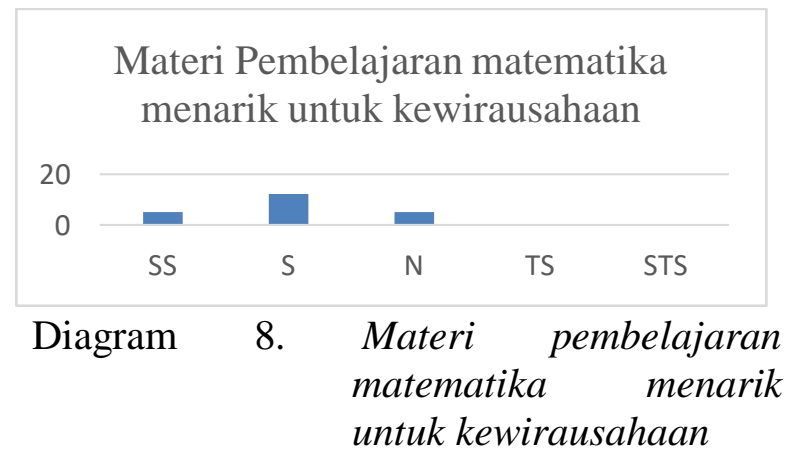

Siswa yang menjawab sangat setuju dan setuju sebanyak 17 siswa ,sedangkan yang menjawab tidak setuju dan sangat tidak setuju sebanyak 0 siswa serta yang netral sebanyak 5 siswa.

Pada data diatas ,sebagian besar siswa setuju $(68 \%)$ tentang materi matematika yang sangat menarik untuk pembelajaran kewirausahaan.

\section{Pertanyaan 9}

Terdapat cerita, gambar, dan contoh yang menunjukkan kepada saya bagaimana manfaat materi pembelajaran matematika dalam bidang wirausaha

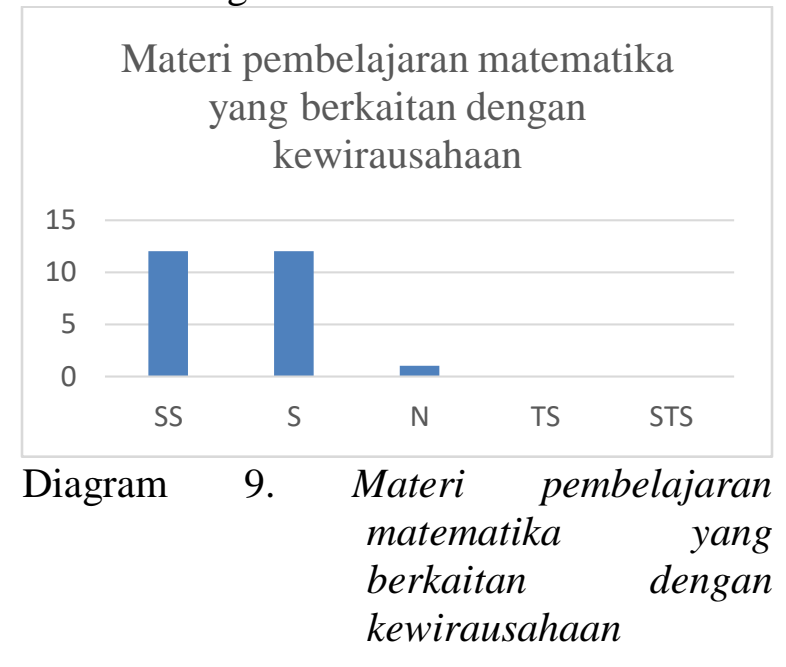

Siswa yang menjawab sangat setuju dan setuju sebanyak 24 siswa, sedangkan yang menjawab tidak setuju dan sangat tidak setuju sebanyak 0 siswa serta yang netral sebanyak 1 siswa.

Pada data diatas, sebagian besar siswa setuju (96\%) tentang banyak materi dan contoh materi pembelajaran matematika yang dapat dipelajari dan berkaitan dengan kewirausahaan.

\section{Pertanyaan 10}

Menyelesaikan pembelajaran matematika dan mendapatkan nilai bagus adalah sangat penting bagi saya. 


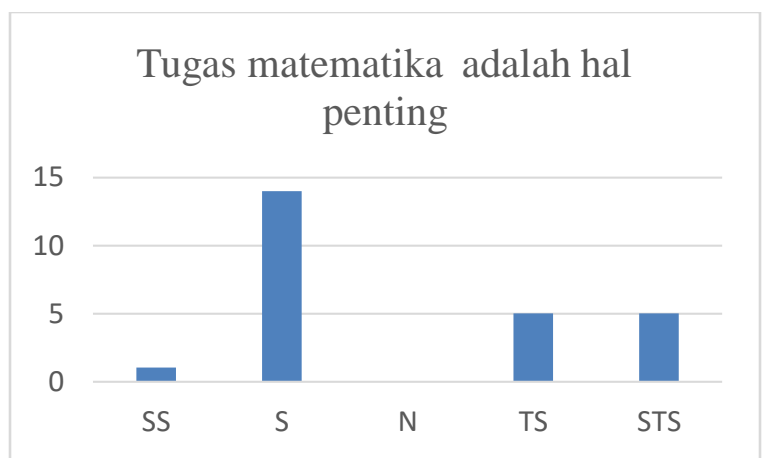

Diagram 10. Tugas matematika adalah hal penting

Siswa yang menjawab sangat setuju dan setuju sebanyak 15 siswa ,sedangkan yang menjawab tidak setuju dan sangat tidak setuju sebanyak 10 siswa serta yang netral sebanyak 0 siswa.

Pada data diatas ,sebagian besar siswa setuju (60\%) tentang menyelesaikan tugas matematika serta mendapatkan nilai bagus merupakan hal penting.

\section{Pertanyaan 11}

Dalam bidang wirausaha diperlukan cara menghitung rata-rata, seperti penghasilan usaha, hal ini dipelajari dalam matematika

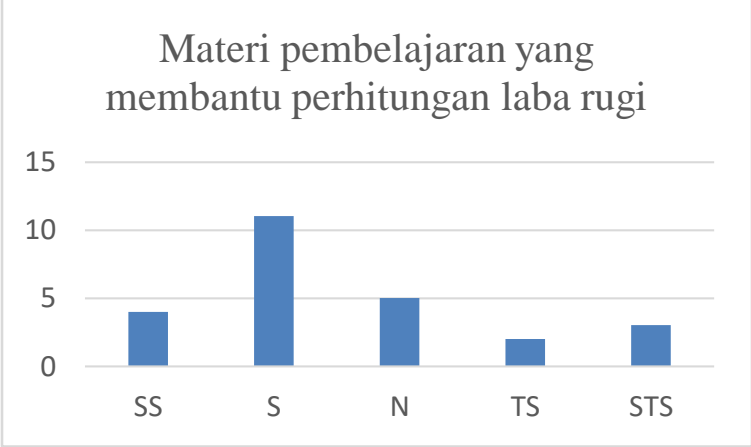

Diagram 11. Materi pembelajaran yang membantu perhitungan laba rugi

Siswa yang menjawab sangat setuju dan setuju sebanyak 15 siswa sedangkan yang menjawab tidak setuju dan sangat tidak setuju sebanyak 5 siswa serta yang netral sebanyak 5 siswa.
Pada data diatas ,sebagian besar siswa setuju $(60 \%)$ tentang materi pembelajaran yang dapat membantu perhitungan laba rugi dalam wirausaha.

\section{Pertanyaan 12}

Pembelajaran matematika sangat abstrak sehingga sulit bagi saya untuk fokus kepada pelajaran.

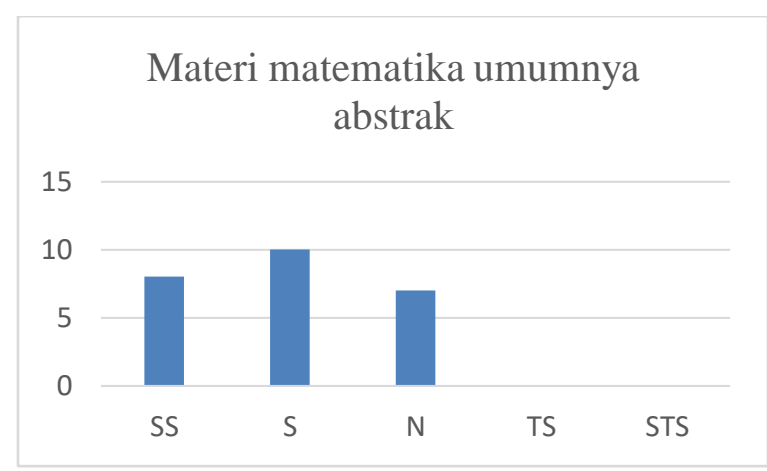

\section{Diagram 12. Materi matematika umumnya abstrak}

Siswa yang menjawab sangat setuju dan setuju sebanyak 18 siswa, sedangkan yang menjawab tidak setuju dan sangat tidak setuju sebanyak 0 siswa serta yang netral sebanyak 7 siswa.

Pada data diatas ,sebagian besar siswa setuju (72\%) tentang materi pembelajaran matematika pada umumnya abstrak, sehingga sulit untuk mempelajarinya secara focus.

\section{Pertanyaan 13}

Selagi saya menekuni pelajaran matematika, saya percaya bahwa saya dapat mempelajari isinya.

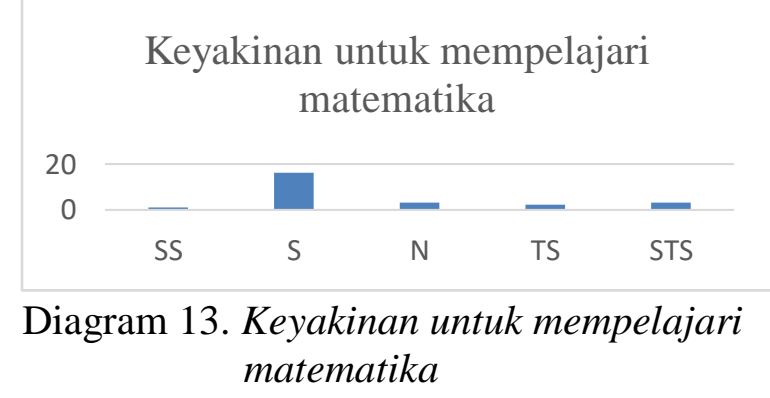


17 siswa yang menjawab sangat setuju dan setuju pada kuesioner ini, sedangkan jumlah siswa yang menjawab tidak setuju dan sangat tidak setuju terdapat sebanyak 3 siswa serta jawaban yang netral sebanyak pada 5 siswa.

Pada data diatas, sebagian besar siswa setuju (68\%) tentang keyakinan untuk mempelajari matematika.

\section{Pertanyaan 14}

Saya sangat senang pada pembelajaran matematika, khususnya tentang ilmu geometri, karena membuat saya berpikir agar menghasilkan produk kreatif dan unik dalam dunia usaha

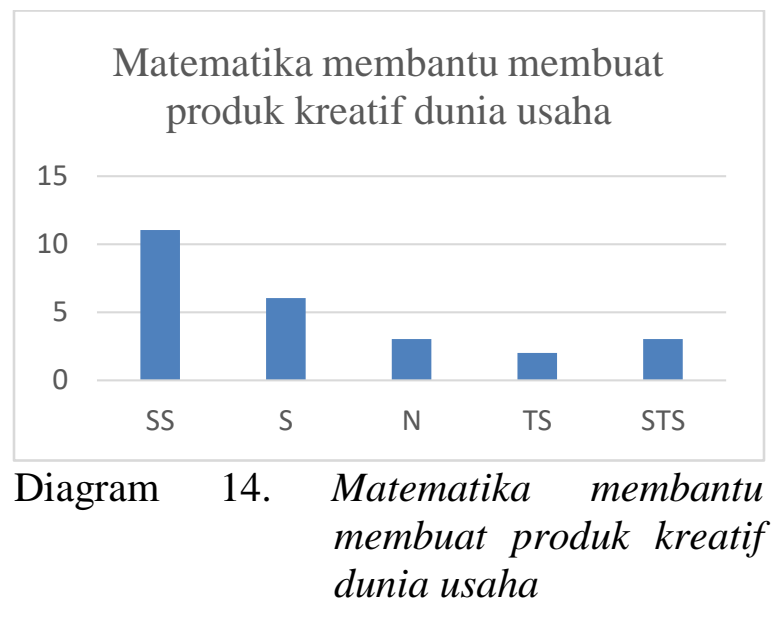

Siswa yang menjawab sangat setuju dan setuju sebanyak 17 siswa, sedangkan yang menjawab tidak setuju dan sangat tidak setuju sebanyak 5 siswa serta yang netral sebanyak 3 siswa.

Pada data diatas, sebagian besar siswa setuju (68\%) tentang pelajaran matematika dapat membuat produk kreatif dalam dunia usaha

\section{Pertanyaan 15}

Isi pembelajaran matematika membantu saya dalam menumbuhkan jiwa wirausaha seperti ketekunan dan keuletan, seperti dalam memecahkan suatu soal matematika

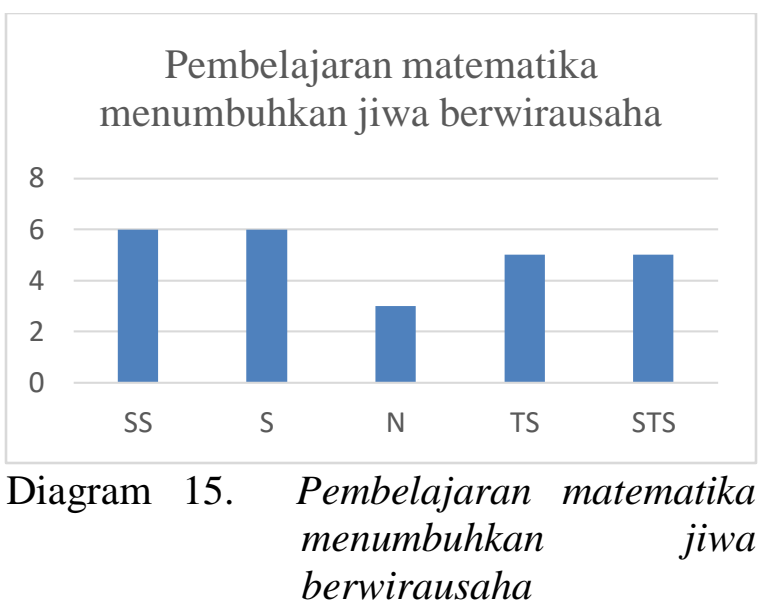

Terdapat 12 siswa yang menjawab sangat setuju dan setuju dikuesioner ini, adapun yang menjawab tidak setuju dan sangat tidak setuju sebanyak 10 siswa serta yang netral sebanyak 3 siswa.

Pada data diatas ,sebagian besar siswa setuju (48\%) tentang pembelajaran matematika menumbuhkan jiwa wirausaha seperti ketekunan dan keuletan.

\section{KESIMPULAN}

Berdasarkan hasil penelitian,siswa SMK Insan Mulia memiliki karakter wirausaha. Hal ini dapat terlihat dari jawaban kuesioner yang sudah diberikan.Matematika memiliki peranan penting untuk menumbuhkan jiwa berwirausaha di SMK Insan Mulia, terutama dalam hal pembelajaran geometeri yang berdampak pada produk kreatif yang sangat berguna dalam dunia usaha.Hambatan yang dihadapi siswa dalam mempelajari matematika dalam menumbuhkan jiwa berwirausaha diantaranya yaitu soal matematika yang sudah diberikan belum dapat menumbuhkan jiwa berwirausaha seperti ketekunan dan keuletan. Hal ini dikarenakan masih banyak kesukaran dalam menjawab soal tersebut.Solusi dalam mengatasi hambatan untuk meningkatkan jiwa berwirausaha siswa SMK Insan Mulia diantaranya, harus memperbanyak soal-soal matematika sehingga menumbuhkan keuletan dan ketekunan yang berdampak 
dalam menumbuhkan jiwa berwirausaha pada siswa.

\section{DAFTAR PUSTAKA}

Anwar, Dessy. 2011. Kamus Lengkap Bahasa Indonesia. Jakarta: Rosda Karya

Alma, Buchari. 2013. Kewirausahaan Untuk Mahasiswa dan Umum. Cetakan 12. Bandung: Alfabeta

Arikunto, Suharsimi. 2013. Prosedur Penelitian Suatu Pendekatan Praktik. Jakarta: Rineka Cipta

Duwi, Priyatno. 2010. Teknik Mudah dan Cepat Melakukan Analisis Data Penelitian dengan SPSS dan Tanya Jawab Ujian Pendadaran. Yogyakarta: Gaya Media

Garjito, Dany. 2014. Berani Berwirausaha. Yogyakarta: Akmal Publishing

Hartanti. 2013. Manajemen Pengembangan Kewirausahaan. Yogyakarta. Tesis Magister, tidak diterbitkan. UNY

Hendro. 2011. Dasar-dasar Kewirausahaan. Jakarta: Penerbit Erlangga

Kementerian Pendidikan Nasional. 2016. Pengembangan Pendidikan Budaya dan Karakter Bangsa. Bahan Pelatihan Penguatan Metodologi Pembelajaran PEDAGOGIK Vol IV No. 2 September 2016

Justin, G. Longenecker. 2011. Kewirausahaan Manajemen Usaha Kecil. Jakarta: Penerbit Salemba Empat
Lexy J, Moleong. 2010. Metode Penelitian Kualitatif. Bandung: Penerbit Rosdakarya

Leonardus, Saiman. 2009. Kewirausahaan. Jakarta: Salemba Empat

Moekijat. 2009. Manajemen Penjualan. Yogyakarta: Penerbit Manajemen Informatika UGM

Riduwan. 2012. Metode dan Teknik Menyusun Tesis. Bandung: Alfabeta.

Riyanti. 2013. Kewirausahaan Dari Sudut Pandang Psikologi Kepribadian. Jakarta: PT Grasindo.

Slameto. 2010. Belajar dan Faktor-Faktor Yang Mempengaruhinya. Jakarta: PT Bina Aksara

Soeryanto, Edy Soegoto. 2009. Entrepreneurship Menjadi Pebisnis Ulung. Jakarta: PT Media Komutindo Kompas Gramedia.

Soertyanto, Eddy. 2009. Entrepreneurship Menjadi Pebisnis Ulung. Jakarta: Penerbit Elex Media Komputindo

Sutrisno. 2011. Metode Research Jilid I. Yogyakarta

Supardi. 2012. Vol 2 No 3. Formatif: Jurnal Ilmiah Pendidikan MIPA. Hal 248262

Sugiyono. 2013. Metode Penelitian Pendidikan Pendekatan Kuantitatif, Kualitatif dan $R \& D$. Bandung: Alfabeta

Suryana. 2009. Kewirausahaan: Pedoman, Praktis, Kiat dan Proses Menuju Sukses. Jakarta: Salemba Empat 
Suherman, Eman. 2010. Desain Pembelajaran Kewirausahaan. Bandung: Alfabeta.

Suprapto, H. A. 2018. PELATIHAN Pembuatan Proposal Rencana Bisnis (Business Plan) Bagi Siswa Madrasah Tsanawiyah Nurul Hikmah Dan Smp Al-Ihsan Guna Meningkatkan Kemampuan Berwirausaha. Abdimas Siliwangi, 1(2), 81-88

Suprapto, H. A. 2018. Strategi Pembelajaran Kewirausahaan Berbasis Teknologi Informasi (TI) Terhadap Peningkatan Minat Mahasiswa Menjadi Wirausaha. Didaktis: Jurnal Pendidikan dan Ilmu Pengetahuan, 18(1).

Suharyadi, dkk. 2010. Kewirausahaan Membangun usaha Sukses Sejak usia Muda. Jakarta: Salemba Empat

Tedjasutisna, Ating. 2009. Memahami Kewirausahaan SMK Tingkat I. Bandung: Armico.

Usman, H \& Raharjo, E. N. 2012. Model Pendidikan Karakter Kewirausahaan di Sekolah Menengah Kejuruan. Jurnal Pendidikan Teknologi dan Kejuruan, Volume 21 No. 2 Hal. 141147

Widiyarto, S., \& Ati, A. P. 2018. Penerapan English Communication Skill Pada Siswa SMP. Abdimas Siliwangi, 1(2), 75-80. 